\begin{tabular}{|c|c|c|}
\hline SiiRT & $\begin{array}{l}\text { Türkiye Tarımsal Araştırmalar Dergisi } \\
\text { dergipark.org.tr/tutad }\end{array}$ & $\begin{array}{l}\text { Turk J Agric Res } \\
\text { 2021, 8(1): 75-92 } \\
\text { ○ TÜTAD } \\
\text { ISSN: 2148-2306 }\end{array}$ \\
\hline $\begin{array}{l}\text { UiNIVERSITESI } \\
\text { Bilimin Isumanda }\end{array}$ & Research Article & $\begin{array}{l}\text { e-ISSN: } 2528-858 X \\
\text { doi: } 10.19159 / \text { tutad.820528 }\end{array}$ \\
\hline
\end{tabular}

\title{
Prospects of Rice Milling Cottage Industry in Niger State of Nigeria
}

\author{
Mohammed Sanusi SADIQ ${ }^{1 *}$, Invinder Paul SINGH ${ }^{2}$, Muhammad Makarfi AHMAD, \\ Sunday Ozovehe RAJI ${ }^{4}$ \\ ${ }^{I}$ Federal University Dutse, Department of Agricultural Economics and Extension, Dutse, NIGERIA \\ ${ }^{2}$ Swami Keshwanand Rajasthan Agricultural University, Department of Agricultural Economics, Bikaner, INDIA \\ ${ }^{3}$ Bayero University Kano, Department of Agricultural Economics, Kano, NIGERIA \\ ${ }^{4}$ Federal University of Technology, Department of Agricultural Economics, Minna, NIGERIA
}

\begin{tabular}{|c|c|}
\hline Received: 03.11 .2020 & Accepted: 17.02 .2021 \\
\hline \multicolumn{2}{|l|}{ ORCID ID (by author order) } \\
\hline (1) orcid.org/0000-0003-4336-5723 (D)orcid.org/0000-0002-18 & t.org/0000-0003-4565-0683 (1D) orcid.org/0000-0002-1825-7324 \\
\hline
\end{tabular}

\begin{abstract}
The study determined the prospect of the rice milling cottage industry in Nigeria's Niger State using cross-sectional data. The data were collected with the aid of a well-structured questionnaire complemented with an interview scheduled from fifty-five (55) active millers chosen through a multi-stage sampling technique. Both descriptive and inferential statistics were used for data analysis. Based on the findings, it can be suggested that the potential of rice milling enterprise in the study area has not been fully explored despite its profitability turnover ratio. The industry is exclusively men enterprise with the majority been low-income earners. Potentials alongside challenges still exist in the rice milling industry as evident by the overwhelming influences of weakness and threat. Millers' age was observed to be the major inducing factor that increases income inequality among the processors. In lieu of the foregoing, the study advised the millers to adopt a defensive strategy to remain afloat in the industry. In addition, there is a need for capacity building enhancement viz. acquisitions of innovative milling skills by the millers, thus enhancing their managerial efficiency.
\end{abstract}

Keywords: Prospect, rice, milling industry, swot, Nigeria

\section{Introduction}

Through its rice Transformation Action Plan under the Agricultural Transformation Agenda, the Nigerian government has made concerted efforts to facilitate the production and processing of rice. The rice transformation action plan, according to Adesina (2012), had the aim of making Nigeria selfsufficient in the development of rice by 2015 . For the intention of ending the $\$ 356$ billion annual import bills spent on this product, the government banned rice imports in 2015.

To encourage local production, new fiscal initiatives such as an increase in the Brown Rice Tariff and a levy on imported finished rice have been implemented by the government to further promote the production of rice. In Nigeria, rice milling still occurs by individual small-scale processors and their cooperative societies at the cottage stage. The activities of the cottage industry varied since it depends on the ability of milling, methods of operation (buying and selling), and the variety of manufacturing operations carried out, and so on. In many production areas in Nigeria, powered paddy processing is still limited (Anonymous, 2002), with most small rice mills in the country operating at about one ton per hour due to lack of adequate paddy available for processing.

Considering the focus put on the mass production of rice by the federal government and some non-governmental organizations, recent economic crisis, population explosion and the ban placed on the importation of rice, organizations continue to create programs that reimburse and provide sufficient information for farmers and investors to go into mass production of rice. 
Several studies on the production, processing, and even marketing of rice have been performed, but very little work has been done on the prospect of the rice processing industry. Rice is a popular food eaten by the wider population and yet the manufacturing company is a fascinating business for just a few individuals. Despite the population boom, the recent economic crisis, and the ban on the importation of rice, there has been a rise in continuous demand for rice, hence the need for investment by people and investors in the production and processing of rice.

Small capital and financial constraints have consistently frustrated the drive towards commercial agriculture in Nigeria (Abiodun, 2011). Small-scale processors belong to the poorest segment of the population of Nigeria and are thus unable to make a substantial investment in agroprocessing /agribusiness/agriprenuer. Rice milling in Nigeria mostly involved small-scale operators and the majority did not engage in producing trade, i.e. buying paddy and selling rice, but only processing paddy for others (producers, traders, or consumers) on a fee basis. The limited number of millers involved in the paddy and rice trade is due to the associated high risks that can result in financial losses from the marketing of both goods.

The dissociation of different processing tasks among different operators gives the post-harvest segment of the rice commodity chain greater flexibility and thus increases its resilience under very unstable and risky market conditions. However, as millers alone have no incentive to improve the quality of their production, this system does not provide the expected mechanism for increasing the quality of milled rice. Another common feature of the rice milling industry is that it has not completely exploited its technological potential ability, and this is due to the seasonal concentration and spatial distribution of paddy production coupled with the presence of a variety of different processing units competing in supplying facilities with each other. As these small mills usually do not buy and store paddy on their own, their operations appear to be confined to the paddy marketing season, and during the rest of the year, their installed capacity remained underutilized.

The high profitability of the rice milling business and the low entry barrier encourage the rapid growth of the small-scale rice milling business, and to this effect, the rapid increase in the number of rice mills, particularly in newly emerging rice-growing areas continues to occur. Therefore, the need for this research to assess the prospects of the rice processing business as it will assist interested investors with key information relating to the prospect of the cottage rice milling industry in the state and the country in general. In the same vein, for miller-traders, the survey showed that it is worth investing in improved technology under the current price level for imported rice to increase the appearance and cleanliness of the local rice to meet the standards of imported rice.

\section{Materials and Methods}

Niger state is located in the middle-belt of Nigeria and lies between latitudes $8^{\circ} 20^{\prime} \mathrm{N}$ and $11^{\circ} 30^{\prime} \mathrm{N}$ of the equator and longitudes $3^{\circ} 30^{\prime} \mathrm{E}$ and $7^{\circ} 20^{\prime} \mathrm{E}$ of the Greenwich Meridian time. The state is characterized by guinea savannah vegetation and experienced both spring and winter annually. The major occupations of the inhabitants are crop farming, livestock rearing, fishing activities, and hunting. In addition, these are complemented with artisanal, public service, petty trading, Ayurveda medicines etc. A multi-stage sampling technique was used to arrive at the representative sample size for the study. The Niger State Agricultural Development Project (NSADP) stratification of the state into three agricultural zones viz. Bida (Zone A), Shiroro (Zone B), and Kontagora (Zone C) were adopted. Subsequently, one agricultural zone viz. Bida was purposively selected because of its comparative advantage in rice production. Thereafter, one Local Government Area (LGA) viz. Mokwa was conveniently chosen due to cost constraints. Because of the small size of the respondents engaged in the rice milling industry in the study area, the sampling frame was adopted as the sample size. Thus, a total of fifty-five millers involved in the milling enterprise formed the representative sample size for the study. Objectives 1 and 3 were achieved using descriptive statistics; objective 2 was achieved using pseudo-profit function; objective 4 was achieved using Strength, Weakness, Opportunity and Threat (SWOT) Analysis, and exploratory factor analysis; and, objective 5 was achieved using Gini coefficient, Tobit regression model and Shapley's decomposition model.

\subsection{Empirical model}

Cost concepts and income measures: Simple cost concepts and income measures used in estimating profitability ratios are given as follows (Sadiq, 2014). The measures are given in Equations 1-4.

$$
\begin{aligned}
& G M=T R-T V C \\
& N I=T R-T C \\
& R O I=G M / T V C \\
& R O R C I=N I / T C
\end{aligned}
$$


Where, TVC, Total variable cost; TC, Total cost (sum of variable and fixed costs); GM, Gross margin; NI, Net income; ROI, Return on Naira invested (short-run); and ROCI, Return on capital invested.

SWOT analysis: A SWOT strategy is a tool for assessing a business working environment. It is an instrument of business market evaluation used by companies and analysts to consider the dynamics of an industry. It allows them to understand what is going on in an industry, i.e. demand-supply statistics, the level of competition within the industry, the state of competition between the industry and other emerging industries, the potential prospects of the industry, taking into account technological advances, the credit system within the industry, and the effect on the industry of external factors. This approach allows an entrepreneur to understand his status relative to other business participants. It helps them identify both the possibilities and risks that come their way and gives them a good idea of the industry's current and potential scenario. The secret to thriving in this ever-changing market environment is to consider and take full advantage of the gaps between one's company and its rivals in the industry. This is the most applicable tool of business assessment in comparison to Porker's 5 forces (Ease of entry, power of suppliers, power of buyers, Availability of substitutes and Competitors) and PEST (Political, Economic, Social, and Technology) analyses. A detailed summary of the SWOT analysis is presented in Table 1 and 2 .

Normalization of values and scaling using PCA: The normalization method is given in Equation 5.

$$
Y_{i j}=b * \frac{x_{i j}-\min \left(X_{i j}\right)}{\max \left(X_{i j}\right)-\min \left(X_{i j}\right)}
$$

Where, $Y_{i j}$ is the normalized value; $X_{i j}$ is the actual value of the indicator; and, $\max \left(X_{i j}\right)$ and $\min \left(X_{i j}\right)$ are the maximum and minimum actual values respectively.

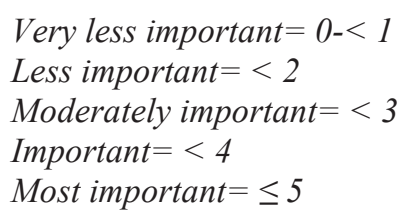

Gini coefficient: The Gini index is defined as a ratio of the areas on the Lorenz curve. The model demonstrates the level of equity of unevenness of any set of numbers, ranging from 0 and 1 . A Gini coefficient of 0 and 1 imply equal and unequal distribution of incomes, respectively. In this way, lower Gini coefficients show the more fair circulation of income among the families, while higher Gini coefficients imply that income is packed in the hands of individuals. Following Sadiq and Samuel (2016); Sadiq et al. (2018a) the formula is given in Equation 6.

$$
G=A / 0.5=2 A=1-2 B
$$

Censored model: Following Sadiq et al. (2018a), the original Tobit model developed by James Tobin a Nobel laureate economist (Tobin, 1958) is given in Equation 7.

$$
Y_{i}^{*}=\alpha+X \beta+\varepsilon_{i}
$$

Where $Y_{i}^{*}$ is censored variable.

$$
\begin{array}{r}
\text { Now, } Y_{i}=0 \text { if } Y_{i}^{*} \leq 0 \\
=Y_{i}^{*} \text { if } Y_{i}^{*}>0
\end{array}
$$

The explicit form is given in Equation 8 .

$$
\begin{aligned}
& \ln Y_{i}^{*}=\alpha_{0}+\beta_{1} X_{1}+\beta_{2} X_{2}+\beta_{3} X_{3}+\beta_{4} X_{4}+ \\
& \beta_{5} X_{5}+\beta_{6} X_{6}+\beta_{7} X_{7}+\varepsilon_{i}
\end{aligned}
$$

Where, $Y_{i}^{*}=$ Income $(\#)$ of $i^{\text {th }}$ miller; $\mathrm{X}_{2}=$ Marital status (married $=1$, otherwise $=0$ ); $X_{3}=$ Age (year); $\mathrm{X}_{4}=$ Household size (number); $\mathrm{X}_{5}=$ Educational level (year); $\mathrm{X}_{6}=$ Experience (year); $\mathrm{X}_{7}=$ Co-operative membership ( $\mathrm{Yes}=1, \mathrm{No}=0$ ); $\mathrm{X}_{9}=$ Type of miller machine (diesel $=1$, electricity= $0) ; \alpha=$ intercept; $\beta_{1-n}=$ estimated coefficients; and, $\varepsilon_{i}=$ error term

Shapley decomposition model: Following Gunatilaka and Chotikapanich (2006), an estimated income-generated model is the first step of the decomposition model. Using Equation (8), the predicted income is given in Equation 9.

$$
\ln \hat{Y}_{i}=\hat{\alpha}_{0}+\hat{\beta}_{1} X_{1}+\hat{\beta}_{2} X_{2}+\hat{\beta}_{3} X_{3}+\hat{\beta}_{4} X_{4}+
$$
$\hat{\beta}_{5} X_{5}+\hat{\beta}_{6} X_{6}+\hat{\beta}_{7} X_{7}$

$\ln \hat{Y}_{i}$ was used to calculate $\hat{G}_{T O T}$ which is the total income inequality as determined by the Gini index. This is inturn determined by the distribution of incomes attributable to the explanatory variables.

Kuznet's ratio: It is the ratio of income received by the top $20 \%$ to that received by the bottom 20 and $40 \%$. It is given in Equation 10 (Akin-Olagunju and Omonona, 2013).

$$
\text { Kuznet's ratio }=\frac{\text { Top } 20 \%}{\text { Bottom }(20 \%+40 \%)}
$$


Table 1. Summary of SWOT

\begin{tabular}{|c|c|c|c|}
\hline Strengths & Weaknesses & Opportunities & Threats \\
\hline Large consumer base (S1) & $\begin{array}{l}\text { High cost of machinery } \\
\text { and equipment (W1) }\end{array}$ & Training support (O1) & Smuggling (T1) \\
\hline $\begin{array}{l}\text { Availability of rice paddy } \\
\text { (S2) }\end{array}$ & $\begin{array}{l}\text { Local means of production } \\
\text { (W2) }\end{array}$ & Large local market $(\mathrm{O} 2)$ & $\begin{array}{l}\text { Government protection } \\
\text { (T2) }\end{array}$ \\
\hline $\begin{array}{l}\text { Pool of available technical } \\
\text { and indigenous knowledge on } \\
\text { rice milling (S3) }\end{array}$ & $\begin{array}{l}\text { Limitation in the access to } \\
\text { information (W3) }\end{array}$ & Quality improvement (O3) & $\begin{array}{l}\text { Climate change reduces } \\
\text { the quality of paddy (T3) }\end{array}$ \\
\hline $\begin{array}{l}\text { Advanced tools for planning, } \\
\text { targeting, and scaling (S4) }\end{array}$ & Low profitability (W4) & $\begin{array}{l}\text { Alternative uses of other sources } \\
\text { of energy like gas, coal is } \\
\text { emerging (O4) }\end{array}$ & $\begin{array}{l}\text { Migration of youth to } \\
\text { urban areas is a threat to } \\
\text { the milling enterprise (T4) }\end{array}$ \\
\hline $\begin{array}{l}\text { Innovation to support the } \\
\text { growth of rice milling } \\
\text { industry (S5) }\end{array}$ & $\begin{array}{l}\text { Inadequate accesses to } \\
\text { financial services (W5) }\end{array}$ & $\begin{array}{l}\text { Availability of export market } \\
\text { that can motivate millers to } \\
\text { improve production/productivity } \\
\text { (O5) }\end{array}$ & $\begin{array}{l}\text { Poor support from other } \\
\text { institutions to "enable" } \\
\text { impact (T5) }\end{array}$ \\
\hline $\begin{array}{l}\text { Readily available market for } \\
\text { the milled product (S6) }\end{array}$ & $\begin{array}{l}\text { Financial instability (donor } \\
\text { dependents) (W6) }\end{array}$ & $\begin{array}{l}\text { Support from research institutes } \\
\text { (O6) }\end{array}$ & $\begin{array}{l}\text { Non-supportive marketing } \\
\text { policy for grains (T6) }\end{array}$ \\
\hline $\begin{array}{l}\text { Productivity-based } \\
\text { technologies (S7) }\end{array}$ & $\begin{array}{l}\text { Less utilization of } \\
\text { appropriate technologies } \\
\text { (W7) }\end{array}$ & Skilled manpower (O7) & $\begin{array}{l}\text { Problem of insurgency } \\
\text { (T7) }\end{array}$ \\
\hline Stable income generation (S8) & Limited capital (W8) & $\begin{array}{l}\text { Adequate provision of credit } \\
\text { (O8) }\end{array}$ & Poor road network (T8) \\
\hline $\begin{array}{l}\text { Improved standard of living } \\
\text { (S9) }\end{array}$ & $\begin{array}{l}\text { Poor market for milled rice } \\
\text { (W9) }\end{array}$ & $\begin{array}{l}\text { Consumer awareness (nutrition, } \\
\text { standards, labels, ) (O9) }\end{array}$ & $\begin{array}{l}\text { Seasonal unavailability of } \\
\text { paddy (T9) }\end{array}$ \\
\hline $\begin{array}{l}\text { Access to credit facilities } \\
\text { (S10) }\end{array}$ & $\begin{array}{l}\text { Unstable market prices } \\
\text { (W10) }\end{array}$ & $\begin{array}{l}\text { Demand for processed rice } \\
\text { products }(\mathrm{O} 10)\end{array}$ & $\begin{array}{l}\text { Unplanned urbanization } \\
\text { drives farmers to marginal } \\
\text { areas (T10) }\end{array}$ \\
\hline $\begin{array}{l}\text { Remunerative milling price } \\
\text { (S11) }\end{array}$ & $\begin{array}{l}\text { Low price offer on paddy } \\
\text { rice milling (W11) }\end{array}$ & Good government policies (O11) & $\begin{array}{l}\text { Adulteration of paddy in } \\
\text { the market (T11) }\end{array}$ \\
\hline $\begin{array}{l}\text { Conducive business } \\
\text { environment (S12) }\end{array}$ & $\begin{array}{l}\text { Low-quality product } \\
\text { (W12) }\end{array}$ & $\begin{array}{l}\text { Growing rice markets (national } \\
\text { and regional) }(\mathrm{O} 12)\end{array}$ & $\begin{array}{l}\text { Epileptic power supply/ } \\
\text { erratic power supply (T12) }\end{array}$ \\
\hline High profitability (S13) & $\begin{array}{l}\text { No legal safeguard in place } \\
\text { (W13) }\end{array}$ & $\begin{array}{l}\text { Price subsidies (tax exemption) } \\
\text { on inputs, e.g., agro-machineries } \\
\text { (O13) }\end{array}$ & Excessive taxes (T13) \\
\hline Value addition (S14) & $\begin{array}{l}\text { Sharp market practices } \\
\text { (W14) }\end{array}$ & $\begin{array}{l}\text { Rice milling enterprise bring } \\
\text { about youth empowerment (O14) }\end{array}$ & High tax rate (T14) \\
\hline Low labor cost (S15) & $\begin{array}{l}\text { High cost of fuel, diesel etc } \\
\text { (W15) }\end{array}$ & $\begin{array}{l}\text { Public private partnerships for } \\
\text { rice milling investment: general } \\
\text { economic growth }(\mathrm{O} 15)\end{array}$ & \\
\hline Low transportation cost (S16) & $\begin{array}{l}\text { High cost of the initial } \\
\text { investment (W16) }\end{array}$ & $\begin{array}{l}\text { Reduced time, labor and costs of } \\
\text { processing rice modern } \\
\text { machinery }(\mathrm{O} 16)\end{array}$ & \\
\hline \multirow[t]{14}{*}{ WEAKNESSES } & High cost of labor (W17) & $\begin{array}{l}\text { Regional collaboration for } \\
\text { innovation in the processing } \\
\text { industry }(\mathrm{O} 17)\end{array}$ & \\
\hline & $\begin{array}{l}\text { High cost of transportation } \\
\text { (W18) }\end{array}$ & Import ban on foreign rice $(\mathrm{O} 18)$ & \\
\hline & Weak branding (W19) & Favorable competition (O19) & \\
\hline & & Adequate labor supply (O20) & \\
\hline & & $\begin{array}{l}\text { Intensification in the production } \\
\text { of rice }(\mathrm{O} 21)\end{array}$ & \\
\hline & & $\begin{array}{l}\text { Maintenance of buffer stock by } \\
\text { the government to avoid glut } \\
(\mathrm{O} 22)\end{array}$ & \\
\hline & & Relatively stable price (O23) & \\
\hline & & Insurance $(\mathrm{O} 24)$ & \\
\hline & & Political stability (O25) & \\
\hline & & Good road network (O26) & \\
\hline & & Adequate power supply (O27) & \\
\hline & & Co-operative milling (O28) & \\
\hline & & Contract marketing (O29) & \\
\hline & & $\begin{array}{l}\text { Formidable co-operative } \\
\text { organization }(\mathrm{O} 30)\end{array}$ & \\
\hline
\end{tabular}


Table 2. SWOT matrix of rice milling industry (Hosseini et al., 2019)

\begin{tabular}{|c|c|c|}
\hline & Strength & Weakness \\
\hline Opportunity & S-O strategies a (Aggressive) & W-O strategies ${ }^{\mathrm{b}}$ (Conservative) \\
\hline Threat & S-T strategies ${ }^{\mathrm{c}}$ (Competitive) & W-T strategies ${ }^{\mathrm{d}}$ (Defensive) \\
\hline
\end{tabular}

\section{Results and Discussion}

\subsection{Socio-economic profile of the millers}

A perusal of Table 3 showed that the milling industry is exclusively men business as evident from the proportion index which is 1.00 . The reason for the sole control of the business empire by the male gender may be connected with the inability of the women to have access and control over productive resources as the business is capital intensive. Likewise, the business is too strenuous as the plant is semi-mechanized, thus making the drudgery nature of the business not compatible with women's statues. Also, the culture sees traditional milling as the confine of women and not the mechanized system, thus affecting women's participation in the study area. It was evident that most of the processors are married people (0.89), thus an indication of being in the business for households' livelihood sustenance. In addition, the twin benefit of social and economic capitals played a vital role in enabling the married processors to venture into this enterprise, as the business is capital intensive. If adequate support is given by the stakeholders, this is a sustainable business in the rice supply chain that will alleviate poverty and create job opportunities for the teeming population in the studied area. It was observed that the business was undertaken by able-bodied men (43.96 \pm 8.53$)$ who fall within the age category recommended by FAO as active and productive. Sequel to this it can be suggested that the milling population in the studied area is productive and active which at all times will be responsive to rice innovative changes that will be introduced in the studied area. This is an indication of efficiency in the supply chain of rice in the studied area in as much as the procurement aspect of the chain will not lag. However, the mean value in relation to the standard deviation value showed an aging population which needs to be replaced so as not to jeopardize the rice food security of the downstream supply chain. The reason for the dominance of the advanced youthful age may be connected to rural-urban migration by the post-teen age category for white-collar jobs which are limited in the studied area. Averagely, most of the processors have a large household size $(9.85 \pm 6.03$ persons) which on one hand will give them access to labor at no cost, thus a reduction in the cost of production; while on the other hand, it will affect the going concern of the business due to excessive households' expenditure which characterized large family size especially where the dependency ratio is high. However, even with the low dependency ratio of households in the study area, the ills outweigh the advantages owing to limited opportunities and high inflation rate at two digits which affect remittances from able-bodied households' members. On average, the education qualification of most of the processors is beyond the first primary school leaving certificate. However, they didn't exceed the junior secondary certificate level. The implication is that processing innovation will have reception but with skepticism as a low level of education is a characteristic of the early majority adoption category. The mean year of experience been 9.55 implies that most of the processors have been in the milling business for quite some time, thus have adequate experience required for managerial efficiency. Thus, having adequate experience will enable them to become rational in resource allocation for optimum profit turnover that will guarantee firm sustainability. It was observed that majority utilized social capital for business pecuniary advantages as evidenced by the co-operative index of 0.67 . This did not come as a surprise given that small-scale firm operators rely mostly on social capital as they lack potential economic capital. Small-scale operators using aggregation as a medium of link with the market stands to benefit from economies of scale viz. bargaining power, bulk discount for input purchase, access to credit: kind or in cash. In addition, the aggregation has been an important instrument used to address the problem of fragmentation in supply chain in advanced developing economies. The result showed that all the processors (1.00) have adequate access to market information on price, demand, and supply of paddy and milled rice prevailing in the near and far markets. It can be suggested that the millers take an informed decision as they are kept abreast with market information updates, thus a barometer for business profit turnover. The result showed that few of the processors relied on fossil fuel-diesel as a source of power for their plant while the majority relied on the national electricity grid to power their plant. It is cheaper to use electricity sourced from the national grid because of subsidy as compared to diesel which has little or no subsidy. Thus, this will enable the 
processors to benefit from profit margin rise as compared to the milling plant which runs on diesel due to a higher cost of production. In the long-run, plants been run on diesel are likely to close shop due to high production costs, thus affecting the business revenue turnover. However, milling plants which run on electricity from the national grid are contained with a frequent power outage, thus affect the supply chain of milled rice. Therefore, power has been the major obstacle in this industry as it makes the processors contain with the decision of whether to remain or leave the business. The proportion index of access to credit been 0.00 , means that none of the processors has access to credit. This may be connected to the poor economic capital of the millers, thus the inability to provide security for credit advancement. Also, there is the issue of policy mismatch which pays little or no attention to the primary processing unit as evidenced by largely skewed credit provision towards the primary production process, thus affecting the supply chain of rice. Poor access to extension service delivery did not puzzle the researchers as extension services is mainly concerned with the backward linkage and not forward linkage in the rice supply chain.
Table 3. Socio-economic profile of the millers

\begin{tabular}{lccc}
\hline Variables & Mean & SD & CV \\
\hline Gender & 1.0000 & 0.0000 & 0.0000 \\
Marital status & 0.89091 & 0.31463 & 0.35315 \\
Age & 43.96 & 8.5309 & 0.19404 \\
Household size & 9.8545 & 6.0351 & 0.61242 \\
Educational level & 8.2545 & 4.4231 & 0.53584 \\
Business experience & 9.5455 & 6.9063 & 0.72352 \\
Co-operative membership & 0.67273 & 0.47354 & 0.70391 \\
Market information & 1.0000 & 0.0000 & 0.0000 \\
Type of miller machine & 0.25455 & 0.43962 & 1.7271 \\
Access to credit & 0.0000 & 0.0000 & 0.0000 \\
Extension contact & 0.054545 & 0.22918 & 4.2017 \\
\hline
\end{tabular}

SD: Standard deviation, CV: Coefficient of variation

\subsection{Profitability estimates of the milling industry}

The overall firm cost and returns structure showed a milling firm that break-even and makes a profit per plant (Table 4). It was observed that during both the rainy and dry seasons a plant records a gross margin cum net income of $\$ 230,835.60$ and $\$ 174,085.20 ; \$ 537,005.60$ and $\$ 462,014.60$, respectively. Furthermore, returns on naira invested cum capital invested were 5.15 and 1.71; and, 3.44 and 1.99 in respect of rainy and drying seasons per plant. This implies that in

Table 4. Costs and return structure

\begin{tabular}{|c|c|c|c|c|}
\hline Items & Unit cost $(\#)$ & Rainy season & Dry season & Pooled \\
\hline Diesel & $\$ 200$ per litre & $3978.21(3.91)$ & $72753.85(31.40)$ & $65138.60(33.74)$ \\
\hline Electricity & \#16 per Kwh & $2416.67(2.38)$ & $2416.67(1.04)$ & $2416.67(1.25)$ \\
\hline MR\&M & & $6407.18(6.30)$ & $12173.87(5.25)$ & $9030.25(4.68)$ \\
\hline Firewood & & $5972.17(5.87)$ & $16000.00(6.91)$ & $11392.76(5.90)$ \\
\hline Hired labor & & $9141.67(8.89)$ & $9141.67(3.95)$ & $9141.67(4.74)$ \\
\hline Sack & & $14598.33(14.34)$ & $39333.33(17.00)$ & $28003.87(14.51)$ \\
\hline Miscellaneous & & $2283.50(2.24)$ & $4425.00(1.91)$ & $3268.06(1.69)$ \\
\hline TVC & & $44797.72(44.02)$ & $156244.40(67.44)$ & $125123.80(64.81)$ \\
\hline Tax & & $241.53(0.24)$ & $241.53(0.10)$ & $241.53(0.13)$ \\
\hline IWC & $\# 34375.27[\$ 107476.1]$ & $3437.53(3.38)$ & $10747.61(4.64)$ & $7667.14(3.97)$ \\
\hline DCI & $20 \%$ & $48819.93(47.96)$ & $48819.93(21.07)$ & $48819.93(25.29)$ \\
\hline Managerial cost & $10 \%$ of $\mathrm{VC}$ & $4251.42(4.40)$ & $15181.94(6.74)$ & $10925.89(5.81)$ \\
\hline TFC & & $56978.76(55.98)$ & $75433.51(32.56)$ & $67654.49(35.19)$ \\
\hline $\mathrm{TC}$ & & 101776.50 & 231677.90 & 192778.30 \\
\hline Income & $\$ 1100$ per bag & 275633.30 & 693250.00 & 622258.30 \\
\hline Gross margin & & 230835.6 & 537005.6 & 497128.9 \\
\hline Net income & & 173856.9 & 461572.1 & 429176.5 \\
\hline ROI & & 5.152843 & 3.43696 & 3.972917 \\
\hline RORCI & & 1.708222 & 1.992301 & 2.222769 \\
\hline
\end{tabular}

N: Naira, IWC: Interest on working capital, MRM: Machine repairs \& maintenance, DCI: Depreciation on capital items, Values in ( ) are percentages.

addition to recouping the amount invested, the millers earned in the short and long-runs 4.15 kobo and 71 kobo, respectively; and 2.44 kobo and 99 kobo during the rainy and drying seasons, respectively. Generally, for credit policy, the financial institutions are advised to advance any term of SME credit for industrial development at a realistic interest rate to these millers, as they will be able to defray it without hindrance to their business going concern ceteris paribus. The profitability ratios of the drying season been higher than that of the rainy season are due to the availability of raw material at low cost due to the glut which characterized the boom period. From the cost component, depreciation on capital items had the highest cost proportion during the rainy season while diesel cost accounted for the highest proportion in the cost items during the off-season. 
The high cost of diesel during the drying season is related to epileptic power supply due to a decrease in the water level of the hydroelectricity generating earth structures in the state. However, for both periods, tax cost had the least contribution in the cost structure. On average, the enterprise is profitable as evidenced by the profitability margins and ratios which were positive and greater than one respectively. Therefore, it can be inferred that the enterprise is profitable in the study area.

\subsection{Millers' perceptions on SWOT of the industry}

The results of the adopted Likert scale assessment for the SWOT analysis presented in Table 5 showed that the processors perceived twelve factors out of sixteen to be the "most important" strengthens of the milling industry. While factors viz. advanced tools for planning, targeting, and scaling (S4), innovation to support the growth of rice milling industry (S5), and low transportation cost (S16); and access to credit facilities (S10) were perceived as "important" and "moderate" strengthens respectively for the milling industry. Kendall's ranking identified a large consumer base (S1) and access to credit facilities (S10) to be the "most" and "least" important perceived strengthens of the milling industry, respectively. Furthermore, Kendall's coefficient of concordance (KCC) being 0.150, implies poor agreement among the respondents with respect to these rankings.

The processors perceived twelve factors out of nineteen to be the "most important" weaknesses of the milling industry while the seven outstanding factors viz. local means of production (W2), limitation in the access to information (W3), low profitability (W4), the poor market for milled rice (W9), low-quality product (W12), high cost of labor (W17) and weak branding (W19) to be "important" weaknesses of the milling industry. The perceived "most" and "least" weaknesses of the milling industry are no legal safeguard in place (W13) and the poor market for milled rice (W9) respectively, as evident by Kendall's ranking. The KCC been 0.61 , implies that there is moderate concordance among the respondents with regard to these rankings.

For the external factors, the processors perceived large local market (O2); quality improvement (O3); consumer awareness on nutrition, standards, and labels (O9); demand for processed rice products $(\mathrm{O} 10)$; growing rice markets (national and regional) (O12); rice milling enterprise brings about youth empowerment (O14); favorable competition (O19); and intensification in the production of rice $(\mathrm{O} 21)$ to be the 'most important' opportunities of the milling industry. However, six factors viz. adequate provision of credit (O8); good government policies (O11); maintenance of buffer stock by government (O22), insurance (O24); political stability (O25); and, good road network $(\mathrm{O} 26)$ were perceived as the "least important" opportunities of the milling industry. The remaining sixteen factors were perceived as 'moderately important' opportunities of the milling industry by the processors. Kendall's ranking showed 'rice milling enterprise brings about youth empowerment (O14) to be the most important opportunity while insurance $(\mathrm{O} 24)$ is the least opportunity of the milling industry. Furthermore, it was observed that there is a weak agreement with respect to these rankings as evident by the $\mathrm{KCC}$ which is 0.293 .

With the exception of the poor road network (T8) which was perceived as the "least important" threat, all the remaining factors were perceived as "most important" threats to the milling industry by the processors. Adulteration of paddy in the market (T11) and government protection (T2) was ranked as the "most" and "least" important threats respectively of the milling industry as shown by Kendall's ranking. The KCC been 0.276 mean that there is a weak concordance among the respondents with respect to these rankings.

The relative weight sum score for each indicator viz. strength, weakness, opportunity, and threat were $6.057,6.205,5.242$, and 6.321, respectively. The internal factor score is -0.148 (6.057-6.205), while the external factor score is -1.079 (5.2426.321). The negative coefficient of the internal factor score implies that weaknesses affecting the milling industry were higher than strengthens influencing the industry. Likewise, the negative coefficient of the external factor score implies that the threats affecting the milling industry outweighed the opportunities in the milling industry. Based on the internal factor evaluation (IFE) and external factor evaluation (EFE), weaknesses and threats were achieved respectively. Thus, for the development of the rice milling industry in the study area, a defensive mechanism strategy is suggested.

\subsection{SWOT determinants}

Principal factor analysis with Varimax rotation matrix was used to reduce the number of variables for the SWOT to an interpretable set of factors. A perusal of the table showed the KMO coefficients for strength, weakness, opportunity, and threat dimensions to be $0.704,0.730,0.730$, and 0.628 , respectively (Table 6). Given that the reduced set of variables for the SWOT meet the necessary threshold of 0.50 recommended by Kaiser (1974), 


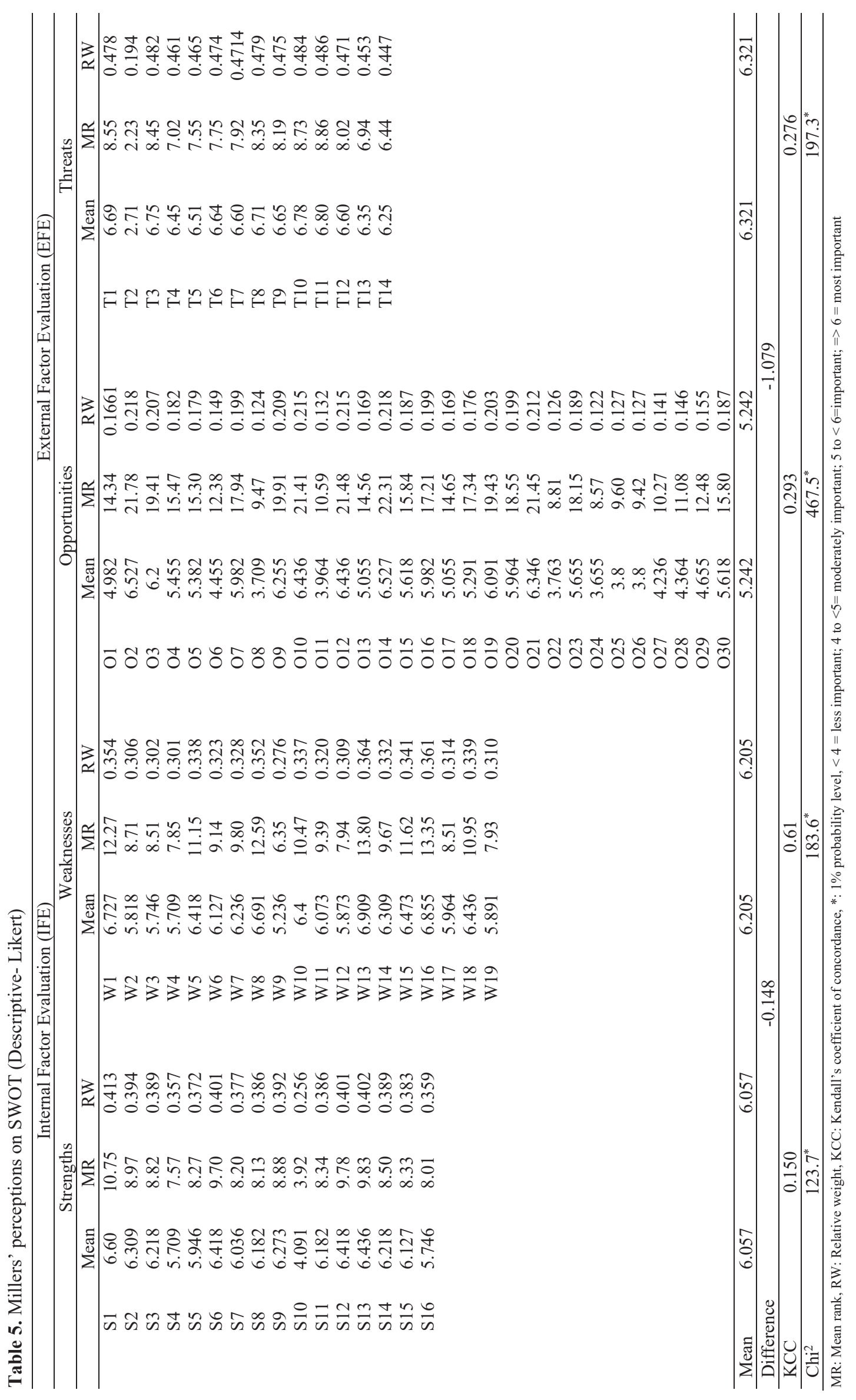


SADIQ et al.

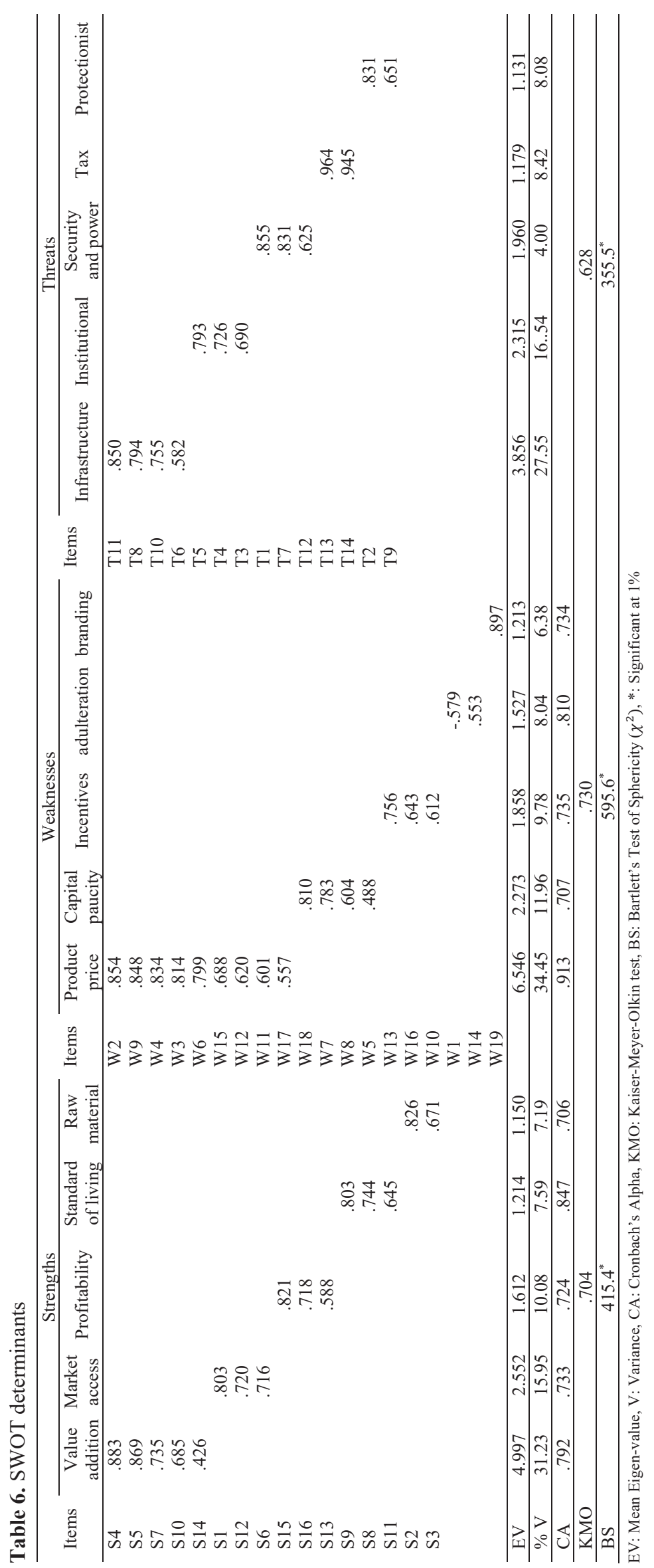




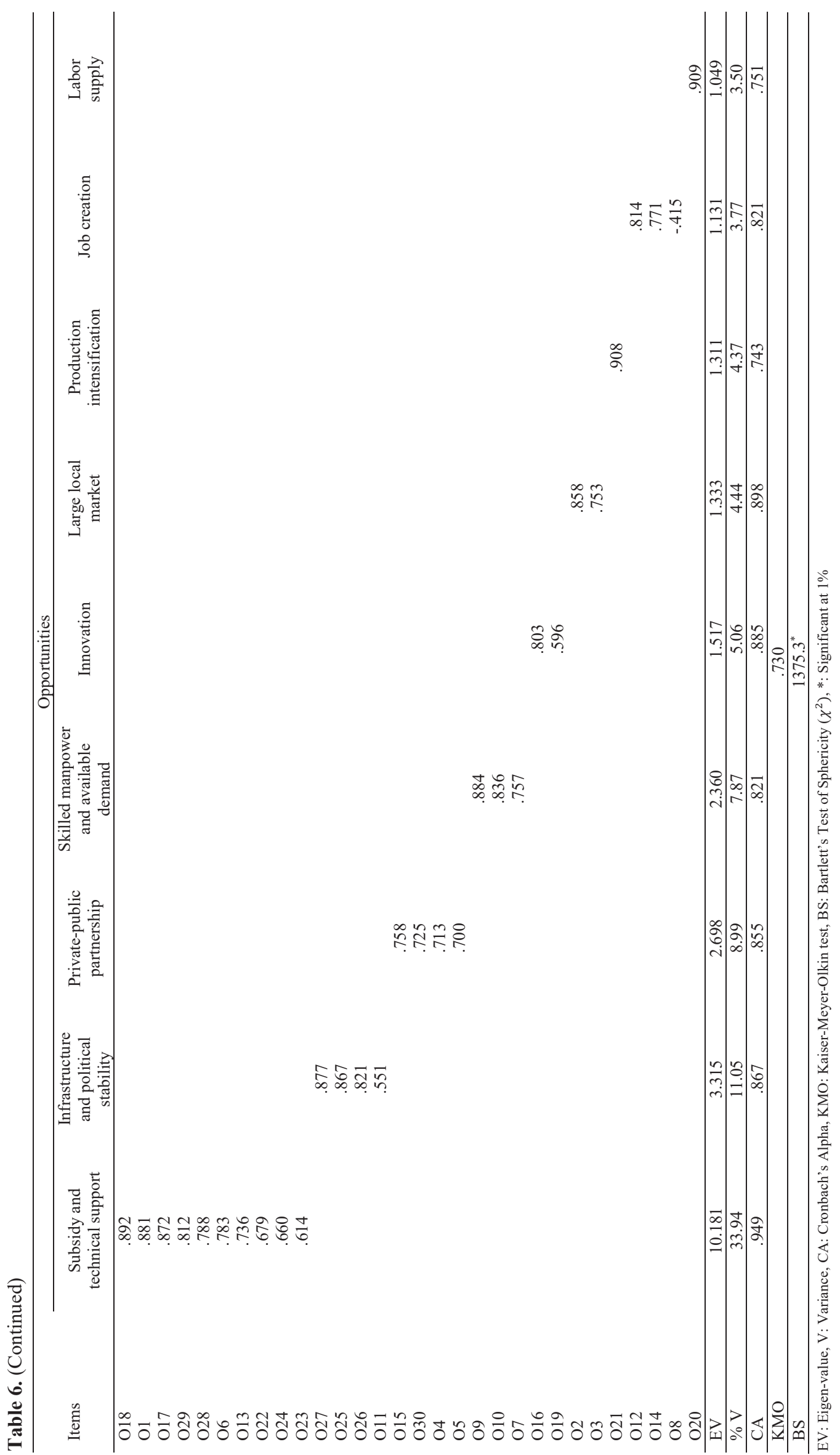


this shows that the samplings are adequate, and the factors were suitable for factor analysis. The KMO value of threat falls within the range of mediocre while that of the remaining indicators fall within the range termed as middling. The high values of each indicator KMO imply that the degree of common variables in each indicator is very large. This means that if PCA is applied, the components will account for fair variance. Bartlett's test of Sphericity for each of the indicators were significant at $1 \%$ probability level, thus indicating that the correlation matrix for each indicator is not an identity matrix-zero matrix: there is a significant relationship or suitable inter-correlations between the variables rotated in the PCA.

Furthermore, in each of the dimensions viz. SWOT, any principal component with an Eigen value greater than one was retained for further analysis. For "Strengthen", "Weakness" and "Threat" dimensions, five principal components each were identified while for the "Opportunity" dimension, ten principal components were retained. Following Sadiq et al. (2017a, 2017b), and Sadiq et al. (2018b, 2018c), loading with a value less than 0.40 in each of the factor loadings (principal components) were excluded. Also, for the principal component with two-factor loadings, the factor load with the highest score is used as the label.

For the "Strengthen", $72.04 \%$ of the total variation in the sixteen variables was explained by five factors. The five extracted factors were labeled as value addition, market accessibility, profitability, the standard of living and raw material. Factor 1 labeled "value addition", accounted for $31.23 \%$ variation, was highly loaded from advanced tools for planning, targeting and scaling (S4); innovation support (S5); productivity-based technologies (S7); access to credit facilities (S10); and, value addition (S14). This factor explained how concerned the millers are about value addition to milled rice. Factor 2 labeled "market accessibility", highly loaded from large consumer base (S1), readily available market for the milled product (S12), and conducive business environment (S6) accounted for $15.95 \%$ of the total variation. The factor showed processors concern on the readily available market for their milled rice. Factor 3 labeled "profitability" and loaded from high profitability (S13), low labor cost (S15), and low transportation cost (S16) accounted for $10.08 \%$ of the total variation. This factor showed producers concern on how to minimize costs and optimize profit in their enterprises. Factor 4 which is labeled "standard of living"; highly loaded from stable income generation (S8), improved standard of living (S9), and remunerative milling price (S11); accounted for $7.59 \%$ of the total variation showed processors concern on obtaining sustainable livelihood from rice milling business. Factor 5 labeled "raw material"; highly loaded from the availability of rice paddy (S2) and a pool of available technical and indigenous knowledge on rice milling (S3); accounted for $7.19 \%$ of the total variation showed processors concern on availability of the raw material for the industry and their capacity building enhancement. Empirical evidence showed internal consistency i.e. inter-correlation among the loadings for each of the principal components as evident by their respective Cronbach's Alpha values which were equal or greater than the acceptable reliability estimate range of 0.70 recommended for social sciences by Nunnally and Bernstein (1994). According to Malhotra (2009), for reliability test, a value of less than 0.70 generally indicates unsatisfactory internal consistency.

For the "Weakness", five factors out of the nineteen variables accounted for $70.26 \%$ of the total variation. These extracted factors were labeled product price, capital paucity, incentives, adulteration, and branding. The first factor labeled "product price" accounted for $34.45 \%$ of the total variation and consists of nine loadings viz. local means of production (W2); limited access to information (W3); low profitability (W4); financial instability (donor dependents) (W6); poor market for milled rice (W9); low price offer on paddy rice milling (W11); low-quality product (W12); high cost of fuel, diesel, etc (W15); and, high cost of labor (W17). This principal component showed that the millers were concerned about poor remunerative price for their products, thus affecting the business going concerned. The second factor labeled "capital paucity"; highly loaded from inadequate accesses to financial services (W5), less utilization of appropriate technologies (W7), limited capital (W8), and high cost of transportation (W18) accounted for $11.96 \%$ of the total variation. This factor revealed millers concern on the effect of capital paucity on their investment going concerned. The third factor labeled "incentives"; highly loaded from unstable market prices (W10), no legal safeguard in place (W13), and high cost of the initial investment (W16); and accounted for $9.78 \%$ of the total variation, showed millers concern on poor policy incentives which affect the development of rice value chain. The fourth factor labeled "adulteration"; highly loaded from the high cost of machinery and equipment (W1), and, sharp market practices (W14); and accounted for 8.04\%, revealed that the processors are worried about product adulteration in the market, thus affecting their business turnover. The fifth factor accounted for $6.38 \%$, labeled "branding" and highly loaded from weak branding (W19) revealed that the millers 
are worrisome over the inability to adopt branding practices for business reputation.

All the five extracted principal components had internal consistency among their respective factor loadings as evident by their respective Cronbach's Alpha coefficients which fall within the range of 0.70 and above.

The results showed that $82.98 \%$ variation in the "opportunity" dimension was explained by nine out of the thirty variables captured in the analysis. The extracted principal components were labeled subsidy and technical support, infrastructure and political stability, private-public partnership, skilled manpower, and available demand, innovation, large local market, production intensification, job creation, and labor supply. It was observed that there is internal consistency among the factor loadings in each of the principal components as evident by their respective Cronbach's Alpha coefficient which is not less than 0.70 . The first factor labeled subsidy and technical support; accounted for $33.94 \%$ of the total variation; is highly loaded from training support (O1), support from research institutes (O6), price subsidies (tax exemption) on inputs (O13), regional collaboration for innovation in the processing industry $(\mathrm{O} 17)$, import ban on foreign rice (O18), maintenance of buffer stock by the government to avoid glut (O22), relative stable price $(\mathrm{O} 23)$, insurance $(\mathrm{O} 24)$, cooperative milling $(\mathrm{O} 28)$ and contract marketing (O29). This factor explained that the millers are concerned about the window of subsidy and technical support in their perception of the opportunities that prevailed in the business environment. The second factor labeled infrastructure and political stability; accounted for $11.05 \%$ of the total variation; consists of adequate provision of credit (O8), good government policies (O11), political stability (O25), good road network (O26), and adequate power supply (O27). This factor explained that the millers are concerned about the opportunities on the availability of infrastructure and political stability in the business environment. The third factor labeled private-public partnerships; accounted for $8.99 \%$ of the total variation; is loaded from alternative uses of other sources of energy (O4), availability of export market (O5), public-private partnerships for rice milling investment (O15), and formidable cooperative organization (O30). This factor explained that the millers are concerned about the publicprivate partnership opportunities that will enhance the industry. The fourth factor labeled skilled manpower and available demand; accounted for $7.88 \%$ of the total variation; is loaded from skilled manpower (O7), consumer awareness (O9), and demand for locally processed rice products $(\mathrm{O} 10)$.
This factor showed that the millers are concerned about the availability of skilled manpower and consumer demand opportunities that are needed for a sustainable business. The fifth factor labeled innovation; consists of reduced time, labor, and costs of processing rice modern machinery (O16), and favorable competition (O19); accounted for $5.06 \%$ of the total variation. This factor explained that the millers while perceiving the opportunities they showed concerns over the availability of innovations that will give them a competitive advantage in the market. The sixth factor labeled large local market; accounted for $4.44 \%$; is highly loaded from the large local market (O2) and quality improvement (O3). This factor explains that the millers are concerned about the wide spatiality in the spread of their products in the studied area. The seventh factor labeled production intensification; highly loaded from intensification in the production of rice (O21); accounted for $4.37 \%$ of the total variation. This factor explained that the millers while perceiving the opportunities in the industry are concerned about large-scale rice production to ensure the availability of paddy for their industry. The eight-factor labeled "job creation"; loaded from growing rice markets (national and regional) (O12) and rice milling enterprise brings about youth empowerment (O14); accounted for $3.77 \%$ of the total variation. This factor explained that the millers in perceiving the opportunities are concerned over the possibility of the industry creating job opportunities for the jobless teeming youths in the processing supply chain. The last factor labeled labor supply; accounted for $3.50 \%$; is highly loaded from only adequate labor supply (O20). This factor showed that the processors while perceiving the opportunities in the industry are concerned about availability of adequate labor supply due to ruralurban migration as the industry is labor intensive.

For the "Threat", five factors were extracted as the principal components as evident by their respective Eigen values which were higher than 1 . In addition, the extracted factors accounted for $74.57 \%$ of the total variation out of the fourteen variables rotated. The extracted factors were labeled infrastructure threat, institutional threat, security and power threats, tax threat, and protectionist threat. Factor 1 labeled infrastructure threat; accounted for $27.55 \%$ of the total variation; is highly loaded from non-supportive marketing policy for grains (T6), poor road network (T8), unplanned urbanization drives farmers to marginal areas (T10) and adulteration of paddy in the market (T11). This factor showed that the millers while perceiving the threats affecting the industry are worried over poor infrastructure policy in the study area. Factor 2 labeled institutional threat; accounted 
for $16.54 \%$; consists of factor loadings viz. climate change reduces the quality of paddy (T3), migration of youth to urban areas (T4), and poor support from other institutions (T5). This factor explained that the millers while perceiving the threats to the industry are concerned about poor support from institutions mandated with tackling environmental and social challenges affecting the industry in the study area. Factor 3 labeled security and power threat; highly loaded from smuggling (T1), the problem of insurgency (T7), and epileptic power supply (T12); accounted for $14 \%$. This factor explained that the millers are worried over insecurity and erratic power supply which plagued the industry. Factor 4 labeled tax threat; accounted for $8.42 \%$; is highly loaded from excessive taxes (T13) and high tax rate (T14). This factor explained that the processors while perceiving the threats affecting the industry, they were concerned about indiscriminate tax regimes and charges. Factor 5 labeled protectionist threat; accounted for $8.08 \%$ of the total variation; is highly loaded from government protection (T2) and seasonal unavailability of paddy (T9). This factor explains that the millers while perceiving the threats affecting the industry were worried over weak fiscal policy on rice viz. tariffs, export substitution, zerotariff for imported machinery, etc; and fluctuation in the availability of paddy. The results showed the presence of internal consistency in each of the extracted principal components as indicated by their respective Cronbach's Alpha coefficients which were not below 0.70 .

Using the PCA to determine the extent of the perception on SWOT, the results showed strengthen perceived to be the "most important" to be "innovation to support the growth of rice milling industry (S5)" while "value addition (S14)" is perceived to be the 'least most important' strengthen (Table 7). The weaknesses perceived to be of the "most and least importance" are limited capital (W8) and sharp market prices (W14) respectively. The results showed "intensification in the production of rice $(\mathrm{O} 21)$ " and "adequate credit provision (O8)" to be the "most and least important" perceived opportunities respectively, in the industry. Also, "smuggling (T1)" and "government protection (T2)" were the "most and least important" threats respectively, perceived in the industry.

On average, most of the respondents have neutral perceptions on strengthens, weaknesses and opportunities in the industry as indicated by the average coefficient value of 2.55. While for the threat, most of the millers have negative perceptions of the threats in the industry (Table 7). Generally, the difference between the average coefficients of strengthen and weakness; and opportunity and threat are $-0.16(2.55-2.71)$ and $-0.49(2.55-3.04)$ respectively. The implication of the negative signs means that weaknesses outweighed strengthens in the industry; likewise, the threats are greater than the opportunities in the industry. Thus, using the foregoing information, based on the internal and external factor evaluations, weaknesses and threats were achieved. Therefore, using the space matrix, the implication is that the millers should adopt a defensive strategy for the development of the smallscale rice milling industry in the study area.

The individual-wise results showed that most of the respondents have high perceptions about the strengths, opportunities, and threats; while very high perception was observed for weakness (Table 8). Overall, the respondent's perception that trailed the SWOT was observed to be high, thus the need to overhaul the supportive environment for competitive rice enterprise in the study area.

\subsection{Income distribution among the millers}

The Gini index of 0.25 as exemplified by the Lorenze curve that is not farther from the line of equality implies a low inequality in income distribution among the millers (Figure 1). Therefore, it can be inferred that the milling industry is dominated by low-income small-scale millers with little variation in their income level. This indicates little variation in the livelihood status of rice millers in the study area. Therefore, policies aimed at income redistribution should be made effective in the study area to bridge the income gap.

\subsection{Income distribution by size among the millers}

A cursory review of the quintile distribution of income showed that the lowest income category received $9.23 \%$ of the total income while the highest income category received $31.77 \%$ of the total income (Table 9). The top $40 \%$ received $56.87 \%$ of the total income while the bottom $40 \%$ received $23.59 \%$. Furthermore, the bottom $60 \%$ received $43.13 \%$ of the total income compared to the top 20 and $40 \%$ that received 31.77 and $56.87 \%$, respectively, of the total annual income. This indicates a low unequal distribution in the annual income. The extent of the inequality in the income distribution was observed to be low as evident by the Kuznets ratio value of 1.347 (Table 9), thus implying low inequality in income distribution.

\subsection{Income determinants among the millers}

The LR $\mathrm{Chi}^{2}$ been within the plausible margin of $10 \%$ degree of freedom implies that the Tobit regression model is fit for the specified equation (Table 10). In addition, it shows that the 


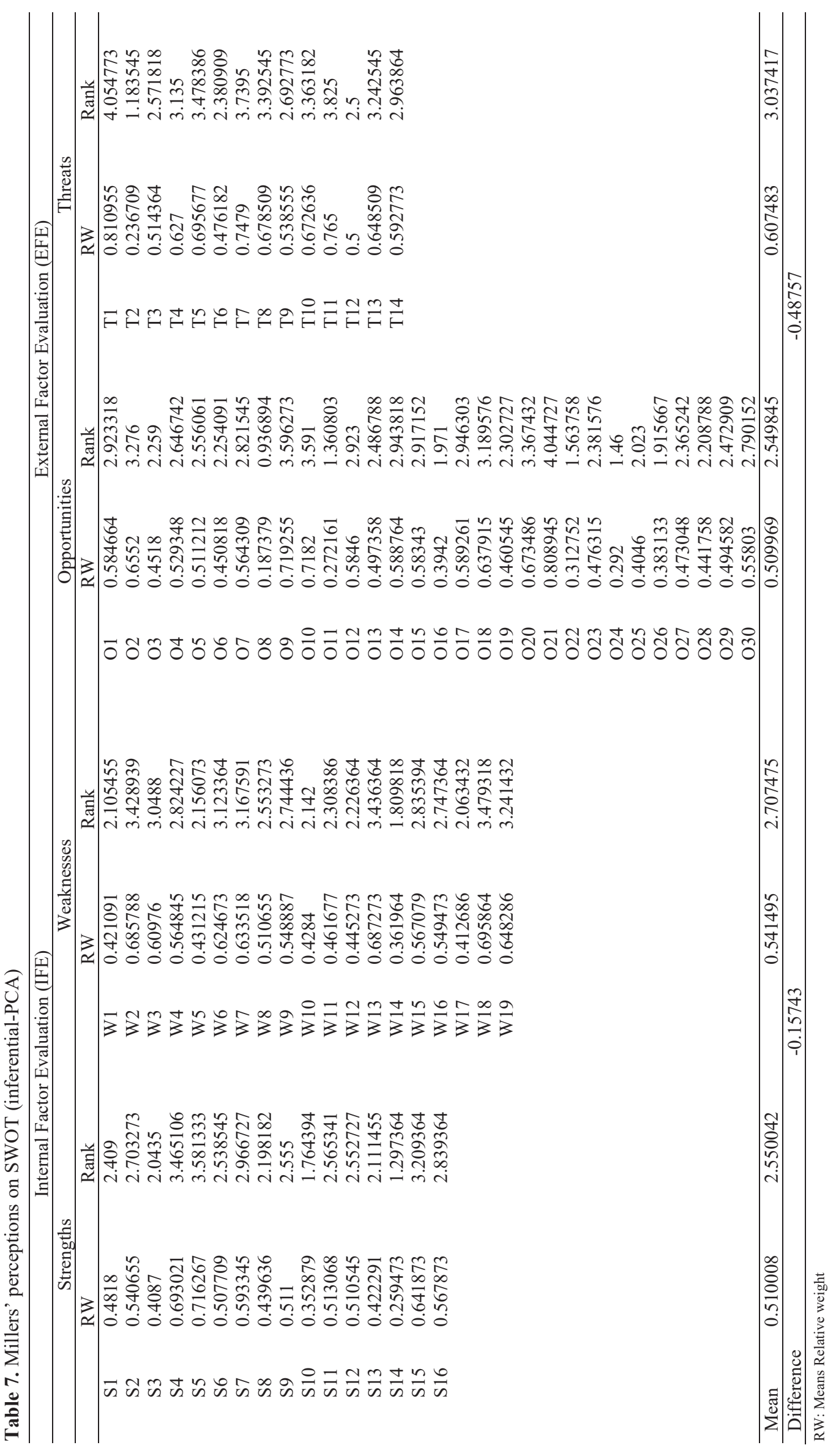


Table 8. Individual-wise SWOT

\begin{tabular}{|c|c|c|c|c|c|}
\hline Firm & Strength & Weakness & Opportunity & Threat & SWOT \\
\hline FM1 & 2.770996 & 2.385045 & 2.464924 & 3.366003 & 2.801586 \\
\hline FM2 & 3.573436 & 2.00446 & 2.457796 & 3.35992 & 2.985689 \\
\hline FM3 & 3.568394 & 2.663381 & 2.558593 & 4.145015 & 3.36416 \\
\hline FM4 & 3.50625 & 2.921027 & 2.562103 & 4.335521 & 3.464545 \\
\hline FM5 & 4.328678 & 2.689905 & 1.716993 & 3.182611 & 3.254392 \\
\hline FM6 & 3.59017 & 2.560845 & 1.75661 & 3.728998 & 3.110184 \\
\hline FM7 & 2.08555 & 3.751118 & 2.383193 & 4.09888 & 3.303859 \\
\hline FM8 & 1.098894 & 3.549157 & 2.183624 & 4.196658 & 3.194173 \\
\hline FM9 & 1.607919 & 3.635114 & 2.335978 & 4.001905 & 3.183296 \\
\hline FM10 & 3.156126 & 3.592835 & 3.814274 & 3.896667 & 3.637244 \\
\hline FM11 & 3.011206 & 4.511244 & 3.500919 & 3.649238 & 3.748111 \\
\hline FM12 & 2.690866 & 3.932909 & 1.910266 & 3.092178 & 3.079839 \\
\hline FM13 & 3.573436 & 2.145952 & 2.457796 & 3.35992 & 3.002687 \\
\hline FM14 & 4.075202 & 4.331397 & 3.046101 & 2.551414 & 3.64564 \\
\hline FM15 & 4.351991 & 4.676068 & 3.69933 & 3.833089 & 4.177499 \\
\hline FM16 & 3.030836 & 3.583983 & 3.585508 & 2.399927 & 3.222006 \\
\hline FM17 & 3.237936 & 4.788812 & 2.725329 & 4.246351 & 3.918008 \\
\hline FM18 & 3.852048 & 4.44832 & 3.073706 & 3.994675 & 3.903761 \\
\hline FM19 & 3.166781 & 4.36087 & 3.463672 & 3.805775 & 3.752536 \\
\hline FM20 & 3.39251 & 4.173838 & 3.684659 & 3.630417 & 3.742242 \\
\hline FM21 & 4.155976 & 4.481053 & 3.376062 & 3.696061 & 3.972375 \\
\hline FM22 & 4.209073 & 3.816429 & 3.576644 & 4.279976 & 3.991185 \\
\hline FM23 & 3.234181 & 4.431915 & 3.245199 & 3.777543 & 3.738254 \\
\hline FM24 & 3.380281 & 4.443216 & 3.806766 & 4.121029 & 3.9764 \\
\hline FM25 & 4.769194 & 4.664693 & 3.208802 & 4.745685 & 4.439081 \\
\hline FM26 & 3.316599 & 4.064868 & 3.705969 & 4.563441 & 3.966272 \\
\hline FM27 & 2.997762 & 4.508664 & 3.776212 & 3.518867 & 3.779833 \\
\hline FM28 & 3.173575 & 4.101162 & 3.356507 & 4.160622 & 3.749072 \\
\hline FM29 & 3.233359 & 3.476505 & 3.20967 & 3.171479 & 3.27718 \\
\hline FM30 & 2.778862 & 4.612444 & 4.034935 & 3.213712 & 3.794112 \\
\hline FM31 & 3.793086 & 3.063831 & 2.657329 & 1.273412 & 2.964041 \\
\hline FM32 & 4.804056 & 4.594472 & 4.410737 & 3.557083 & 4.391108 \\
\hline FM33 & 3.829414 & 4.295583 & 3.313651 & 3.627433 & 3.800265 \\
\hline FM34 & 3.536428 & 3.872664 & 2.999338 & 3.947622 & 3.62671 \\
\hline FM35 & 3.327291 & 3.754579 & 3.149521 & 4.224201 & 3.661678 \\
\hline FM36 & 3.100382 & 3.504323 & 3.772775 & 4.745685 & 3.878742 \\
\hline FM37 & 3.389041 & 3.719734 & 3.793072 & 4.682106 & 3.9558 \\
\hline FM38 & 2.947024 & 4.155141 & 3.657741 & 4.158327 & 3.792412 \\
\hline FM39 & 3.448718 & 4.200075 & 3.744085 & 4.618527 & 4.051988 \\
\hline FM40 & 4.207536 & 3.696527 & 3.340244 & 4.650317 & 4.035266 \\
\hline FM41 & 2.920707 & 3.775556 & 4.039006 & 4.100487 & 3.765543 \\
\hline FM42 & 3.505034 & 4.782984 & 3.773607 & 4.618527 & 4.239229 \\
\hline FM43 & 4.259025 & 4.484933 & 3.22691 & 3.342132 & 3.906155 \\
\hline FM44 & 3.105137 & 4.140898 & 4.23246 & 4.596493 & 4.091018 \\
\hline FM45 & 4.755607 & 4.052649 & 4.706056 & 4.735701 & 4.581019 \\
\hline FM46 & 2.998119 & 2.829891 & 3.910947 & 3.730031 & 3.429389 \\
\hline FM47 & 3.202645 & 3.273513 & 1.851872 & 3.656353 & 3.134273 \\
\hline FM48 & 3.961212 & 3.841992 & 4.152068 & 3.186054 & 3.818956 \\
\hline FM49 & 3.549551 & 3.579223 & 3.029964 & 4.866416 & 3.879967 \\
\hline FM50 & 4.322778 & 4.46428 & 3.857961 & 3.943491 & 4.162557 \\
\hline FM51 & 4.874782 & 4.759302 & 4.334089 & 4.618527 & 4.655374 \\
\hline FM52 & 3.237936 & 3.553961 & 4.314733 & 3.88083 & 3.789141 \\
\hline FM53 & 4.144712 & 4.005685 & 4.219037 & 4.792967 & 4.311921 \\
\hline FM54 & 4.156619 & 4.368522 & 3.892043 & 4.498026 & 4.241142 \\
\hline FM55 & 4.276688 & 4.01478 & 3.604177 & 4.553112 & 4.141505 \\
\hline Average & 3.501302 & 3.856224 & 3.321119 & 3.904135 & 3.736008 \\
\hline Difference & -0.07098 & & -0.1166 & & \\
\hline
\end{tabular}




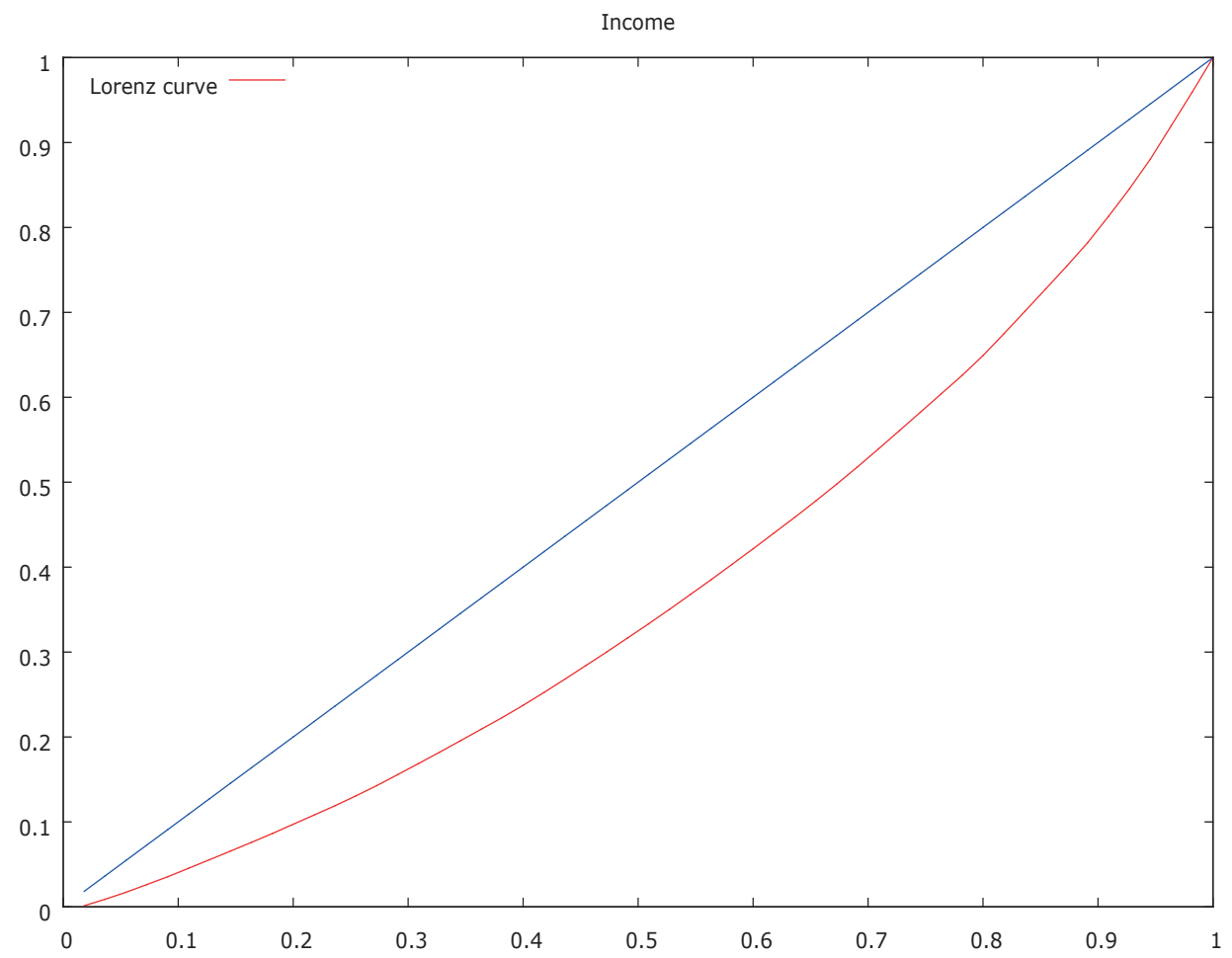

Figure 1. Income distribution of rice processors Sample Gini coefficient $=0.25159$, Estimate of population value $=0.256249$

Table 9. Quintile distribution of Income

\begin{tabular}{lcc}
\hline Quintile & Mean & $\begin{array}{c}\text { Share in total income } \\
(\%)\end{array}$ \\
\hline First & 736904.8 & 9.228655 \\
Second & 1147059 & 14.36524 \\
Third & 1560000 & 19.53672 \\
Fourth & 2004333 & 25.10135 \\
Fifth & 2536667 & 31.76804 \\
\hline Kuznet's ratio & & 1.346452 \\
\hline
\end{tabular}

predictor variables captured by the model are different from zero at a $10 \%$ probability level. The diagnostic test viz. variance inflation factor (VIF) showed an absence of multicollinearity as evidenced by the VIF values of the predictor variables which were below the margin of 10.0. However, the residual of the model was non- normally skewed as shown by the $\mathrm{Chi}^{2}$ test statistic which is different from zero at $10 \%$. Though, the non-normality of a residual is not considered a serious problem as most data in their natural form do not follow a normally skewed pattern.

The results showed annual income to be influenced by age, education, co-operative membership, and type of miller machine as indicated by their respective parameter estimates which were within the acceptable margin of $10 \%$ probability level. The positive significance of the age coefficient points to labor productivity efficiency of the youth engaged in the business, thus an increase in income. The marginal and elasticity implications of an increase in age by a year will lead to an increase in income by 0.015 and $0.046 \%$

Table 10. Income determinants among the millers

\begin{tabular}{|c|c|c|c|c|c|}
\hline Variables & Coefficient & Standard error & t-stat & Elasticity & VIF \\
\hline Intercept & 12.9433 & 0.36945 & $35.03^{* * *}$ & - & \\
\hline Marital status & -0.137665 & 0.19775 & $-0.69^{\mathrm{NS}}$ & -.0082863 & 1.790 \\
\hline Age & 0.01525 & 0.008427 & $1.81^{*}$ & .0456988 & 4.354 \\
\hline Household size & 0.01429 & 0.01517 & $0.94^{\mathrm{NS}}$ & .0106773 & 3.655 \\
\hline Educational & 0.03805 & 0.012097 & $3.15^{* * *}$ & .0233004 & 1.324 \\
\hline Experience & 0.002754 & 0.009777 & $0.282^{\mathrm{NS}}$ & .0019374 & 2.109 \\
\hline Co-operative membership & -0.12718 & 0.075257 & $1.69^{*}$ & -.0056665 & 1.244 \\
\hline Machine type & 0.12645 & 0.073608 & $1.718^{*}$ & .0025175 & 1.380 \\
\hline $\mathrm{LR} \mathrm{Chi}^{2}$ & $26.81(0.0003)^{* * *}$ & & & & \\
\hline Normality test & $11.86(0.002)^{* * *}$ & & & & \\
\hline
\end{tabular}

LR: Likelihood ratio, VIF: Variance inflation factor 
respectively. In the same line, the positive significance of the education coefficient points to the effect of managerial efficiency of the processors, thus enhancing the return that accrued to the business. The marginal and elasticity implications of an increase in educational level by a year will lead to an increase in annual income by 0.039 and $0.023 \%$ respectively. The positive coefficient of the machine type showed that millers who used diesel-powered plants generated a higher income margin against their counterparts who used electricity-powered plants. This is due to the erratic power supply which affected even processing operation, thus affected the income inflow of the electric-powered plant millers. Therefore, the marginal and elasticity implications of using dieselpowered plant will make the income inflow of the diesel-powered plant millers to be higher than that of their counterparts that use electricitypowered plant by 0.139 and $0.003 \%$, respectively. The negative coefficient of co-operative membership shows that millers that did not belong to social organizations have less income in comparison to their counterparts who benefited from social capital. Thus, the marginal and elasticity implications of not being a member of a social organization will lead to a decrease in a miller's income by 0.117 and $0.006 \%$ respectively, in comparison to their counterparts who belong to co-operative associations.

\subsection{Determinants of income inequality among the millers}

The results of Shapley's decomposition on the determinants of income inequality are shown in Table 11. The empirical evidence showed that approximately $54.56 \%$ of the total inequality which amounts to a Gini index of 0.137 was explained by the predictor variables while $45.54 \%$ was unexplained by the residual. Except for the experience variable, all the remaining idiosyncratic variables had positive Gini coefficient values, thus implying they are income inequality increasing factors. The Gini value of the experience variable been 0 , means it is neither an increasing nor decreasing income inequality-factor. Education and marital statuses are the highest $(34.92 \%)$ and lowest $(1.07 \%)$ contributing factors respectively that increase income inequality as evident by their respective Gini values of 0.088 and 0.0027. The Gini coefficient values of age, household size, experience, type of milling machine, and co-operative membership were $0.015, \quad 0.010,0.00,0.0111$ and 0.009 , respectively. In order of the above, their contributions to the overall income inequality are $6.28,4.03,0,4.42$, and $3.74 \%$ respectively. Therefore, except for income flow from experience, it can be inferred that income flow from all the explanatory variables contributed positively to the increase in income inequality among the millers.

Table 11. Factor contribution to the level of inequality

\begin{tabular}{lll}
\hline Variables & Gini value & $\%$ \\
\hline Marital status & 0.00269 & 1.069076 \\
Age & 0.015805 & 6.282036 \\
Household size & 0.010126 & 4.024828 \\
Educational level & 0.087864 & 34.92355 \\
Business experience & 0 & 0 \\
Co-operative membership & 0.011122 & 4.420872 \\
Type of miller machine & 0.009399 & 3.735692 \\
Gini index (Estimated) & 0.137006 & 54.45606 \\
Residual & 0.114584 & 45.54394 \\
Gini index (Actual) & 0.25159 & 100 \\
\hline
\end{tabular}

The educational level been an income inequality increasing factor implies that millers with low educational level are challenged by managerial inefficiency which has a negative consequence on rational allocation of productive resources, thus yielding low income when compared to their counterpart with high level of education. Age being an inequality increasing factor implies that labor efficiency of productive and active youths involved in the industry enable them to earn a higher income than their counterparts who are relatively old. The relative high return turn-over by plants that runs on diesel owes to even processing, thus makes their income to be higher than that of their counterparts who used electric powered machine. The co-operative membership been associated with increasing income inequality showed that the benefits of pecuniary advantages that accrued to millers that belong to social associations made their income to be higher than that of their counterparts who did not belong to co-operative associations. The marital status been an income inequality increasing factor points to the fact that married millers apart from the benefits of social and economic capitals inherent in marriage; having a responsibility to carter for will encourage them to work towards a viable and sustainable enterprise, thus gives them higher income than their counterparts who are single.

The household size been an increasing income inequality factor implies that large households are likely to be constrained with lower income, little or no savings, and increased poverty. Coker (1999) as cited by Akin-Olagunju and Omonona (2013) attributed a high level of poverty to household size and reported that the larger the household size, the higher the tendency of a household been in poverty. However, labor productivity could be enhanced, and the market created for milled products, thus the need to work out a lasting balance. 


\section{Conclusion and Recommendations}

Based on the findings it can be inferred that the milling industry is an exclusive men enterprise and is dominated by low-income earners. Furthermore, the empirical evidence showed that the annual income of the millers is influenced by education, age, co-operative membership, and the type of milling machine. Age was found to be the major inducing factor that increased income inequality. Though, except experience, all the remaining idiosyncratic variables are inducing factors that increase income inequality among the millers. The milling industry is not in the comfort zone as the industry has been challenged by weakness and threats as the former and latter outweighed the industrial inherent strengthens and opportunities. In lieu of the foregoing, the millers are advised to adopt a defensive mechanism strategy for the sustainability of the industry. Based on the foregoing, the following recommendations are proffered:

1) Both governmental and non-governmental organizations should assist in empowering women with economic capital to enable them mainstream into this industry as they are active participants in the forward integration of the rice supply chain.

2) There is a need for capacity building program i.e. the millers should acquire skills on how to operate rice mill to increase efficiency and productivity, thus enhancing their managerial efficiency.

3) The millers should be willing and ready to take a risk by adopting innovations in the milling business to increase their production efficiency.

4) Effort should be made to strengthening the existing co-operative association in the study area so that millers can benefit more pecuniary advantages inherent in co-operative society.

\section{References}

Abiodun, E., 2011. Banks and Agricultural Funding in Nigeria. (http://www.thisdaylive.com/articles/banksand-agriculture-funding-in-nigeria/101838), (Date of access: 23.04.2020).

Adesina, A.A., 2012. Unlocking the Potential of Agriculture in Sub-Saharan Africa: Nigeria's Transformation Agenda for Agriculture. Abuja, Nigeria: A Report of Federal Ministry of Agriculture and Rural Development.

Akin-Olagunju, O.A., Omonona, B.T., 2013. Determinants of income inequality among rural households of Ibadan, Oyo State, Nigeria. Nigerian Journal of Rural Sociology,13(3): 27-37.

Anonymous, 2002. Annual Survey of Crop Production Conditions in Nigeria. Nigerian Institute of Social and Economic Research (NISER), Annual
Monitoring Research Programme, University of Michigan.

Coker, J.B., 1999. Household Sample Surveys in the Study of Poverty: The FOS experience. Center for Econometric and Allied Research, University of Ibadan, Ibadan, Nigeria.

Gunatilaka, R., Chotikapanich, D., 2006. Inequality Trends and Determinants in Sri-Lanka1980-2002: A Shapley Approach to Decomposition. A Working Paper 6/06, Department of Econometrics and Business Statistics, Monash University, Australia.

Hosseini, F., Sadighi, H., Mortazavi, S.A., Farhadian, H., 2019. An E-commerce SWOT analysis for export of agricultural commodities in Iran. Journal of Agricultural Science and Technology, 21(Suppl.): 1641-1656.

Kaiser, H.F., 1974. An index of factorial simplicity. Psychometrika, 39(1): 31-36.

Malhotra, N.K., 2009. Marketing Research: An Applied Orientation. Prentice Hall, Upper Saddle River, New Jersey.

Nunnally, J., Bernstein, I., 1994. Psychometric Theory, $3^{\text {rd }}$ Edition. McGraw-Hill, New York.

Sadiq, M.S., 2014. Profitability of small-scale maize production in Niger State of Nigeria. Indian Journal of Economics and Development, 10(3): 205-210.

Sadiq, M.S., Samuel, P.E., 2016. Lucid investigation of cost efficiency of small-scale poultry broiler farms in Niger State of Nigeria. International Journal of Innovative Research and Review, 4(4): 9-23.

Sadiq, M.S., Singh, I.P., Ahmad, M.M., Lawal, M., Kamaldeen, N., Sani, T.P., 2018c. Determining the perceived constraints affecting cassava farmers in Kwara State of Nigeria. FUDMA Journal of Agriculture and Agricultural Technology, 4(2): 235247.

Sadiq, M.S., Singh, I.P., Ahmad, M.M., Lawal, M., Shehu, H.O., Sani, T.P., Yusuf, T.L., 2018 b. Perceived constraints affecting homestead fish farming in Kogi State, Nigeria. FUDMA Journal of Agriculture and Agricultural Technology, 4(2): 255266.

Sadiq, M.S., Singh, I.P., Isah, M.A., Grema, I.J., Umar, S.M., 2017b. Strategy of minimizing the cost of cultivation vis-à-vis boosting farm income of smallholder maize farmers in Niger State of Nigeria using Efficient Measurement System (EMS). Indian Journal of Economics and Development, 13(2a): 728734.

Sadiq, M.S., Singh, I.P., Singh, N.K., Eije, O.C., 2017 a. Measuring efficiency of farm productive resources used in yam production in Benue State of Nigeria: implication for sustainable farm economy. Sumerianz Journal of Agriculture and Veterinary Science, 1(2): 30-42.

Sadiq, M.S., Singh, I.P., Singh, N.K., Yakubu, G.M., 2018a. Improving economic efficiency and TFP of lowland paddy rice farmers in Kwara State of Nigeria. Journal of Agricultural Sciences, 13(2): 110-129.

Tobin, J., 1958. Estimation relationship for limited dependent variables. Econometrica, 26: 24-36. 